\title{
The Phylogenetic Study of the White-Bellied Sea Eagle [Haliaeetus leucogaster (Gmelin, 1788)] Based on DNA Barcoding Cytochrome-c Oxidase Subunit I (COI)
}

\section{Riri Wiyanti Retnaningtyas, Windri Hermadhiyanti, and Dwi Listyorini}

Department of Biology, Faculty of Mathematics and Natural Sciences, State University of Malang, Jalan Semarang 5, Malang 65145, Indonesia

\section{Abstract}

Even though not yet considered as endangered, White-bellied Sea Eagle's global population is decreasing due to illegal hunting, bird trading, and deforestation. So far, there hasn't been any report regarding the phylogenetic study of the White-bellied Sea Eagle inhabiting the coastal regions of Java. Moreover, there hasn't been any report on the genetic data, especially COI gene, of the White-bellied Sea Eagle living in coastal area of Java. Thus, in this research, two individuals of Heliaeetus leucogaster (Gmelin, 1788); are compared based on its COI gene sequence to the member of genus Haliaeetus to determine their position in the phylogenetic tree of genus Haliaeetus. COI gene amplification is performed using Forward primer BirdF1 5' - TTC TCC AAC CAC

Corresponding Author: Riri Wiyanti Retnaningtyas riri.suryadinata@gmail.com

Received: 11 February 2017 Accepted: 08 March 2017

Published: 26 March 2017

Publishing services provided by Knowledge $\mathrm{B}$

(c) Riri Wiyanti Retnaningtyas et al. This article is distributed under the terms of the

Creative Commons Attributior

License, which permits unrestricted use and redistribution provided that the original author and source are credited.

Selection and Peer-review under the responsibility of the ICBS Conference Committee.

G OPEN ACCESS AAA GAC ATT GGC AC-3' and Reverse primer BirdR2 5' ACT ACA TGT GAG ATG ATT CCG AAT-3'. The phylogenetic analysis using MEGA6 with Maximum Likelihood method shows that Haliaeetus leucogaster in this study is related to Haliaeetus leucocephalus (Linnaeus, 1766), Haliaeetus pelagicus (Pallas, 1811), and Haliaeetus albicilla (Linnaeus, 1758).

Keywords: phylogenetic study; Heliaeetus leucogaster (Gmelin, 1788); DNA barcoding, Cytochrome-c Oxidase Subunit I (COI).

\section{Introduction}

Here The White-bellied Sea Eagle [Helioeetus leucogaster (Gmelin, 1788)]; is one of the top order predators in the coastal ecosystem in Indonesia. It plays role as the key species of the marine ecosystem and serves as an indicator on how human affects the ecosystem due to its sensitivity to human disturbance [1]. This species has such vast distribution from the Indian west coast, China, to all over South East Asia including Indonesia, Papua New Guinea, and Australia [2].

It is reported that the adult White-bellied Sea Eagle has the total body length of around $70 \mathrm{~cm}$ to $80 \mathrm{~cm}$, total wing span of $1.8 \mathrm{~m}$ to $2 \mathrm{~m}$, and the wing width of around $50 \mathrm{~cm}$. The White-bellied Sea Eagle's body is covered in grey and white feathers. The bird's iris color is dark brown with black pupils along with visible bulges located 
at the upper part of the eyes. Yellowish scale covers the skin on the tarsus to the claws [3]. The major habitats favored by White-bellied Sea Eagles include inshore seas, islands, coasts, estuaries and terrestrial wetlands [4]. White-bellied Sea Eagles usually nest on high trees such as Casuarina longistifolia, rock piles by the sea, cliffs, and offshore islands [2]. The eagle preys mostly on marine fish, though small mammals and freshwater fish are also included in the bird's diet [5]. Adults are generally sedentary, while juveniles are more prone to dispersing. White-bellied Sea Eagles are mostly seen singly or in pairs; the largest group ever reported overseas is 14 , most of which are juveniles [6].

The current global population of White-bellied Sea Eagles-including adults, nonbreeders and juveniles-is estimated to be over 10000 [6]. However, numbers have declined in places like Thailand, mainland Southeast Asia and southern Australia [6, 7]. According to IUCN Red List, this species is categorized as least concerned (LC), regardless the global population of this species is decreasing [8] due to illegal hunts, wildlife illegal trading, deforestation, and another human activities of similar nature which have resulted in the declining of the species population [5].

So far, there hasn't been any report regarding the phylogenetic study of the Whitebellied Sea Eagle inhabiting the coastal regions of Java. Furthermore, there also hasn't been any report on the genetic data, especially COI gene, of the White-bellied Sea Eagle living in coastal area of Java. In this study, we aim to obtain the genetic data by means of DNA barcoding to recontruct the phylogenetic tree. DNA barcode is an identification technique using a short mtDNA sequence to accurately identify organisms to the species level [9]. COl is one of mitochondrial genes used as barcode since it is relatively stable and short, around 648 bp long and has low variability ( $1 \%$ to $2 \%$ ) [10].

The White-bellied Sea Eagle belongs to the family Accipitridae along with the other member of the Haliaeetus genera Haliaeetus leucocephalus (Linnaeus, 1766), Haliaeetus pelagicus (Pallas, 1811), and Haliaeetus albicilla (Linnaeus, 1758). By comparing the sequence of $\mathrm{COI}$ gene of Haliaeetus leucogaster (Gmelin, 1788) with COI genes from the rest of the Haliaeetus genera, we can determine the position of $H$. leucogaster in the phylogenetic tree. The data obtained from the $\mathrm{COI}$ sequence can construct a phylogenetic tree to describe the relationship amongst organisms with their closest ancestors [11]. This research is aimed to determine the relationship of the White-bellied Sea Eagle with the other members of the Haliaeetus genera.

\section{Materials and Methods}

The subjects in this research are two domesticated White-bellied Sea Eagles [Haliaeetus leucogaster (Gmelin, 1788)]). This research is conducted by extracting total DNA from blood taken from pectoralis subclavial vein according to the High Pure DNA Template PCR kit of Roche protocols with several modifications. To amplify the target gene, the PCR is performed using the universal primer BirdF1 $5^{\prime}$-TTCTCCAACCACAAAGA CATTGGCAC $-3^{\prime}$ as the forward primer, and reverse primer BirdR2 5 '-ACTACATGTGAGATG ATTCCGAATCCAG-3' [12]. The amplicons are then sequenced in First BASE Laboratories, Malaysia. The COI gene data is analyzed using DNA Baser to obtain the consensus 


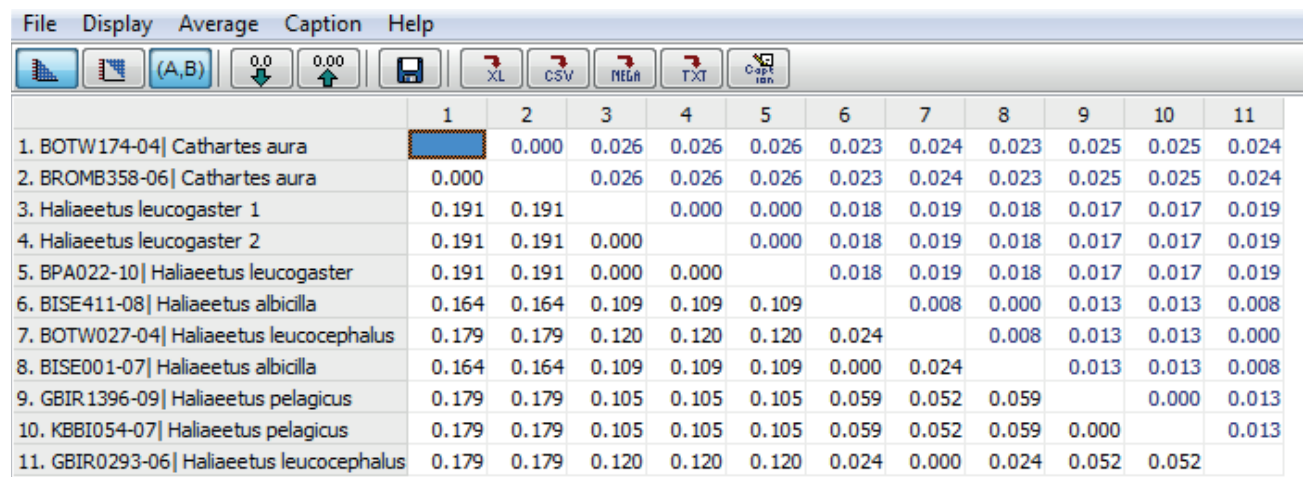

Figure 1: The genetic distance analysis shows that the genetic distance between the sample $\mathrm{H}$. leucogaster and the $H$. leucogaster voucher BPA022-10 is 0.00 .

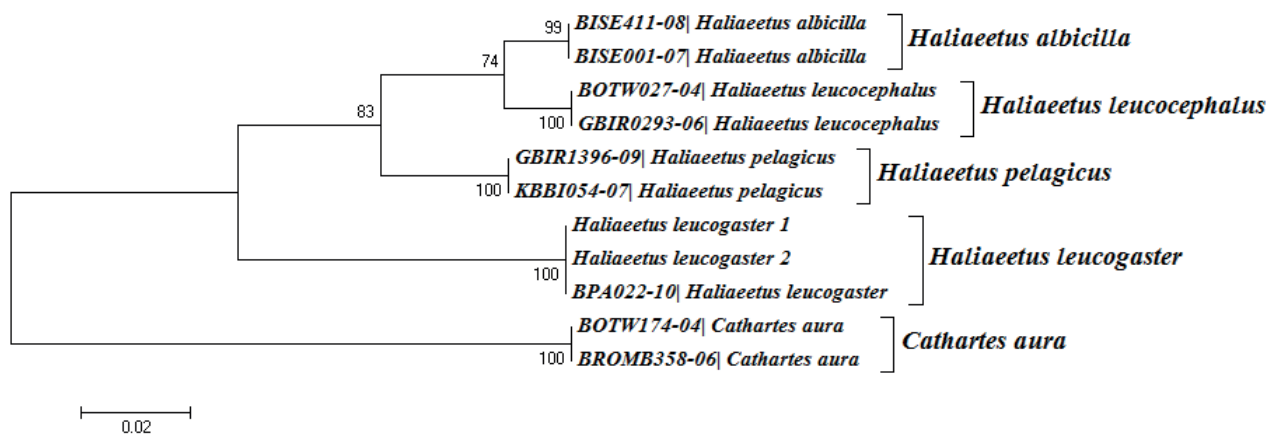

Figure 2: Phylogenetic topology using the Maximum Likelihood which indicates that $H$. leucogaster is closely related to $H$. pelagicus, H. albicilla, and H. leucocephalus.

of the forward and reverse strands. Afterwards, the consensus is aligned using the ClustalX software to examine the unique characteristics of $\mathrm{COI}$ gene of $\mathrm{H}$. leucogaster. The phylogenetic topology is arranged using the MEGA6 in Maximum Likehood (ML) and Kimura-2 logarithmic calculation model with Cathartes aura as out group.

\section{Results and Discussion}

The phylogenetic study is conducted to determine the kinship of the $H$. leucogaster with another species of the Haliaeetus genera. The phylogenetic tree topology shows that the sample $H$. leucogaster in this research belongs to the same species with the other $H$. leucogaster reported in the BOLDSystem whose voucher number is BPA022-10 (see Figure 2). It is shown by the bootstrap value of 100 and being in the different branch with the other species of Haliaeetus. $H$. leucogaster species is closely related with $H$. pelagicus, $H$. Leucocephalus and $H$. albicilla (see Figure 2 ). The genetic distance analysis also indicates that the sample $H$. leucogaster has a closer kinship with $H$. pelagicus with the genetic distance of 0.105 compared to $\mathrm{H}$. leucocephalus-the genetic distance of which is 0.120 (see Figure 1).

The multiple alignment result of the $\mathrm{COI}$ gene of $\mathrm{H}$. leucogaster with $\mathrm{H}$. leucocephalus, H. pelagicus, H. albicilla and Cathartes aura shows that the White-bellied Sea Eagles possess the automorphic characteristics which is shown by the different bases compared 


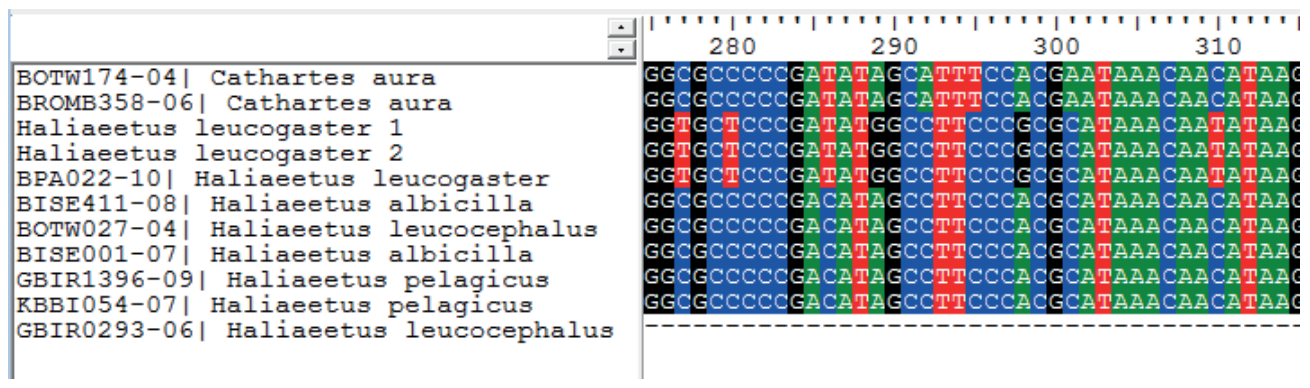

Figure 3: The automorphic characters possessed only by the $H$. leucogaster species .

to the other reference Haliaeetus species. There are approximately 20 different bases, some of which are the base number 277 indicated by $T$, the number 280 indicated by the base T, number 286 indicated by the base T, the number 289 indicated by a base $\mathrm{G}$, the number 298 indicated by the base $\mathrm{G}$, and the number 310 shown by base $T$ (see Figure 3).

\section{Conclusions}

According to this study, it can be concluded that the White-bellied Sea Eagles [Haliaeetus leucogaster (Gmelin, 1788)] in this study belong to the same species as the White-bellied Sea Eagle existing in the database (Haliaeetus leucogaster voucher BPA022-10) and is closely related to Haliaeetus leucocephalus (Linnaeus, 1766), Haliaeetus pelagicus (Pallas, 1811), and Haliaeetus albicilla (Linnaeus, 1758).

\section{Acknowledgements}

The author would like to acknowledge the following people for their technical assistance and helpful discussions: Dwi Listyorini, Windri Hermadhiyanti, Muthia Naila Mazieda, Jeroen van den Hurk.

\section{References}

[1] LA. Romin and JA. Muck, "Guidelines for raptor protection from human and land use disturbances.US Fish and Wildlife Service," in Muck JA. Guidelines for raptor protection from human and land use disturbances. US Fish and Wildlife Service, p. 10, UT, Salt Lake City, 1999.

[2] J. M. Shephard, C. P. Catterall, and J. M. Hughes, "Long-term variation in the distribution of the White-bellied Sea-Eagle (Haliaeetus leucogaster) across Australia," Austral Ecology, vol. 30, no. 2, pp. 131-145, 2005.

[3] R. Retnaningtyas Wiyanti, W. Hermadhiyanti, DA. Rahayu, and D. Listyorini, "The identification of the White-Bellied Sea Eagle (Haliaeetus leucogaster) based on morphological characteristics," in The 3rd International Conference on Biological Science, 2013., KnE Life Sciences, P. Rarastoeti, AST. Woro, RN. Tri, NM. Siti, and R. Ganies A, Eds., vol. 2, pp. 588-591, 2015. 
[4] J. M. Shephard, J. M. Hughes, C. P. Catterall, and P. D. Olsen, "Conservation status of the White-Bellied Sea-Eagle Haliaeetus leucogaster in Australia determined using mtDNA control region sequence data," Conservation Genetics, vol. 6, no. 3, pp. 413429, 2005.

[5] S. J. S. Debus, "Biology and diet of the White-bellied Sea-Eagle Haliaeetus leucogaster breeding in northern inland New South Wales," Australian Field Ornithology, vol. 25, no. 4, pp. 165-193, 2008.

[6] J. Ferguson-Lees and DA. Christie, Raptors of the world, Houghton Mifflin Harcourt, New York, 2001.

[7] BirdLife. International, "Species factsheet: Haliaeetus leucogaster. The IUCN Red List of Threatened Species," [Internet]Accessed, 2015, http://www.birdlife.org.

[8] P. D. N. Hebert and T. R. Gregory, "The promise of DNA barcoding for taxonomy," Systematic Biology, vol. 54, no. 5, pp. 852-859, 2005.

[9] P. D. Hebert, A. Cywinska, S. L. Ball, and J. R. deWaard, "Biological identifications through DNA barcodes," Proceedings of the Royal Society B: Biological Sciences, vol. 270, no. 1512, pp. 313-321, 2003.

[10] T. R. Gregory, "Understanding Evolutionary Trees," Evolution: Education and Outreach, vol. 1, no. 2, pp. 121-137, 2008.

[11] P. D. N. Hebert, M. Y. Stoeckle, T. S. Zemlak, and C. M. Francis, "Identification of birds through DNA barcodes," PLoS Biology, vol. 2, no. 10, 2004. 